\title{
What's left, what's been done and what next? England's 2000 Rural White Paper: Town council activities and a survey of town clerks
}

Commonwealth Journal of Local Governance

\section{Gordon Morris}

University of Exeter

Centre for Rural Policy Research

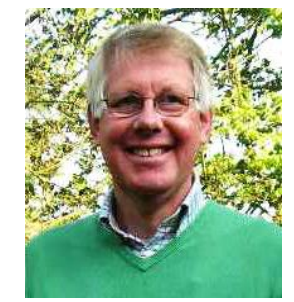

\begin{abstract}
The research discussed in this paper was prompted by the writer's interest in the roles of England's small country ("market") towns. It has two aims: first, to discover the extent to which the work programmes announced in the British government's Rural White Paper (RWP 2000) (DETR-MAFF 2000) are recognised by town clerks, and second, to find out what town councils are doing, either on their own, or with others, and to gauge the potential and desire that they have for a greater degree of autonomy. In both cases the data was gathered from an online questionnaire sent to town clerks.
\end{abstract}

\section{Introduction}

In the United Kingdom voter turnout is low, anger with politicians high (Guardian/ICM 2013), inequality likely to grow (Cribb, Joyce and Phillip 2012: 46) and, following devolution of powers in the late 1990s to Scotland, Wales and Northern Ireland, Scottish independence is now a possibility. With terms such as 'localism', 'Big Society', 'double-devolution' and 'neighbourhood planning' relatively familiar, if not wholly understood, and politicians' rhetoric more about the rights of 'communities' than the powers of democratic authorities, now is a good time to explore the place of elected town councils in relation to community development.

The survey questionnaire was sent to town clerks because of the importance of country towns and their councils, both to rural England, and, by definition, to RWP 2000's vision, '... of a living, working, protected and vibrant countryside'. (DETR-MAFF 2000: 5). Whilst only one of the RWP 2000 programmes, the Market Towns Initiative (MTI), was designed to encourage community-led development in and around towns (DETR-MAFF 2000: 73-88), others were relevant. These were the Beacon Towns Programme (BTP), One-Stop Shops (OSS), Gateway Stations (GS), Vital Villages (VV), Rural Transport Partnerships (RTP), Rural Housing Enablers (RHE), and the Local Heritage Initiative (LHI). They, together with the MTI, are outlined in Appendix 1. 
RWP 2000 was the second rural white paper in five years. It built on work outlined in the first (DoEMAFF 1995), and was a catalyst for almost a decade of work, and a move towards an integrated rural policy (Woods 2005: 132). In the event, the move rather petered out. However, the programmes ran their course, and evaluations, although partial and uncoordinated, suggest that they and related work, eg, Yorkshire's Renaissance Market Towns (Genecon 2011), were broadly successful (CA 2004, Defra 2004, Powe, Hart, \& Shaw 2007, ekosgen 2009, Morris 2010).

In the years since the programmes ended the national and regional central government organisations responsible for them have been closed, or merged with other organisations. Consequently, it is difficult to find out if the programmes are remembered, and their legacies recognised. This is disappointing, because the programmes represented a significant financial investment by the British taxpayer, involved a lot of people, many of whom were volunteers, in a lot of work, and provided opportunities to develop, implement and assess various approaches to community-led development. It is hoped, therefore, that this research will remind people of the work that was done, and that it will also draw attention to the need for a consistent and long-term approach to community-led development, and to the importance of regular monitoring and formal evaluation of this type of work.

The paper takes the reader through an explanation of the research method, and a discussion about the results, after which some conclusions are drawn. First, a brief overview of the changes that have taken place in local government in country towns is given.

\section{Town councils' changing roles}

Many country towns were, until 1972-74 (Stevens 2006: 30-31), administrative centres known as urban district councils, in which rural district councils, responsible for the surrounding rural areas, were also often located. These councils, based on a multiplicity of pre-existing organisations, including poor-law-union and sanitary-authority areas (Odgers 1899: 131), were created in 1894 (pp13-14). They inherited wide-ranging powers and responsibilities for health, housing, and highways (pp134-140). These were eventually increased to include, for example, newly developed services, such as electricity supply (Greene 2007). During the post-war years, however, increasing national integration of infrastructure and services, coupled with doubts, by national government, about the calibre of councillors, and a related desire to instil, 'a more 'corporate' approach to the way local authorities did business ...' (Stevens 2006: 30) led to the creation of today's larger district authorities, into which the urban and rural districts were incorporated. 
Consequently, country towns, previously urban districts in their own right, as well as bases for rural district councils, lost status as administrative and political centres. The successor council to the urban district became a town council. Although the council boundary remained unchanged, the powers of the new, town council were on a par with those of the - much smaller - outlying village parish councils.

As can be imagined, no matter the strength of the arguments made in favour of the changes, they were not universally popular (comments made to the writer over the years by town councillors and others suggest that discontent lingers). The civic pride and history of these often ancient settlements, their popularity as places in which to live (both for locals, and the active early retired, who are often professionally qualified and experienced), their relatively large populations and revenues, together with, in some places, significant management responsibilities for local facilities, suggest that town councils should be well placed to assume greater responsibilities, in return for greater autonomy. The research questionnaire, discussed in the next section, was designed both to explore this assumption, and to find out how well the RWP 2000 programmes are remembered.

\section{The survey}

The questionnaire was primarily designed for quick and easy completion via simple 'yes-no' boxticking, although respondents could expand on their answers in text boxes. The programme-related questions asked clerks about their awareness of, and involvement in, each of the RWP 2000 programmes, together with the status of any continuing work.

The remaining questions sought information about: membership of organisations; involvement in central government policies around 'localism' and the 'Big Society'; the nature of any council responsibilities that were previously held by higher tier authorities, or other agencies; their status as Quality Parish Councils (QPC), or interest - or otherwise - in becoming a Quality Parish (NALC 2008); and the provision of a foodbank.

The link to the questionnaire was included in an explanatory email sent to town clerks. It was sent to clerks for four reasons: 1) town councils are, unlike essentially volunteer-led partnerships, permanent organisations, and so are easy to locate and contact; 2) as statutory bodies, councils are publically financially accountable, and are able, therefore, to employ staff, and manage accounts and budgets for programmes and projects; 3 ) the clerks' awareness, and that of their councillors, is a gauge by which the extent to which the programmes are still recognised locally can be measured; 4) clerks are the obvious people to provide information about council activities. 
The questionnaire was sent to the 230 towns involved in the MTI (Powe, Hart \& Shaw 2007: 5), and to 358 others classified as market towns (London Ancestor 2013, Wikipedia 2013) selected on the basis of council status and eligibility for the MTI. These criteria were considered sufficient to provide a degree of confidence that the clerks in these towns in 2000 would have been aware of RWP 2000 . Population was not a particular consideration, because, '... there is no consensus on a population basis for market towns'. (Shepherd 2009: 2).

As a follow-up to the main survey, non-responders were asked for their reasons for not responding. The question was asked out of interest, but also in an attempt to persuade clerks to complete the main questionnaire. In total, 249 questionnaires were completed, of which 199 related to the main survey, while 50 clerks completed the follow-up questionnaire, and a further three submitted written comments.

Although the final response rate, $33 \%$, is reasonable, it compares poorly with the $83 \%$ achieved from a survey conducted in early 1991 of 1,000 town and village councils (Ellwood, Nutley, Tricker, and Waterson, 1992 p11). The present survey, of town council clerks only, took place between May and August, 2013. This was unfortunate, as, unknown to the writer, it coincided with budget preparations. This fact, coupled with comments by clerks about pressure of work and the amount of information they are now expected to provide ('I get inundated with questionnaires!!!', wrote one), may explain the difference in response rates.

\section{Towns surveyed, populations, responders and non-responders}

The 588 towns surveyed varied in population from 529 to 83,641 (Figure 1); the average being 9,557. The majority, 460, are within the population band of 2,000 to 20,000 most generally recognised for smaller country towns (RERC 2005: 46, Shepherd 2009: 4).

Figure 1: The 588 towns surveyed (population bands of 1,000)

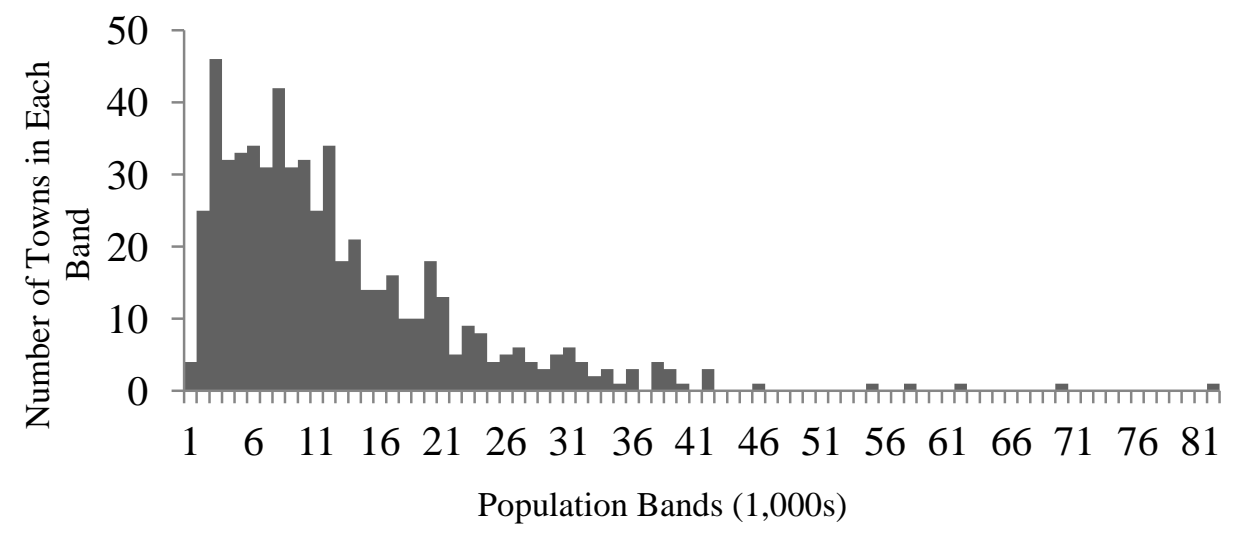


In 559 cases, the population band extends to approximately 31,000 (Figure 2), a higher limit that takes into account the rural employment and service functions of some larger towns (RERC 2005: 38). Although 199 completed returns were received, three clerks completed the survey twice, and some of their answers, given in each of the two questionnaires they completed, were contradictory, and so have been excluded from the analysis. Therefore, a total of 193 questionnaires from 196 towns were analysed.

The towns from which responses were received were reasonably evenly distributed geographically (Map 1). Distribution by population and involvement in the MTI is illustrated in Figure 3.

Figure 2: The 559 towns surveyed with populations between $529 \& 30,635$

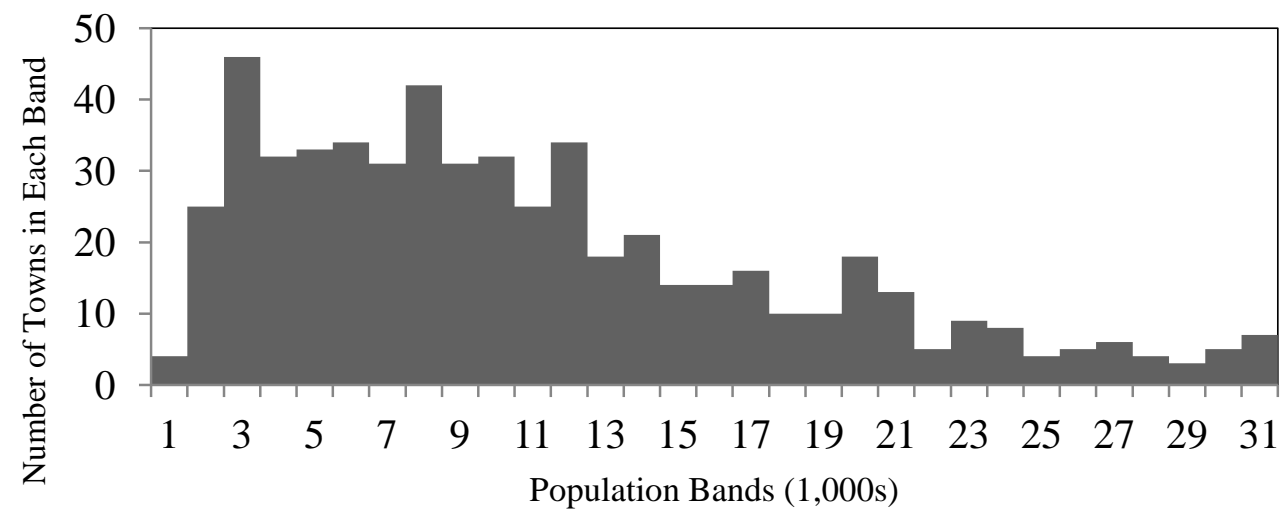

Figure 3: The 196 towns that responded to the survey (population bands of 1,000)

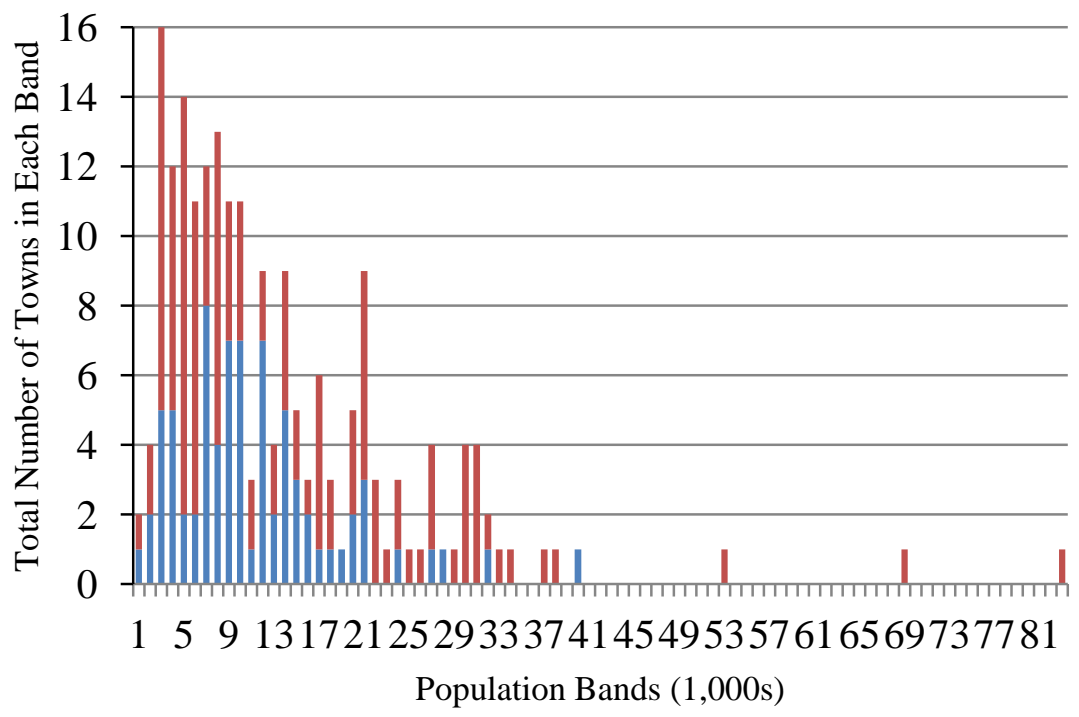

- Non MTI Towns

- MTI Towns 
Map 1: Geographical distribution of towns in England with Populations between 1,500 and 40,000 (survey participants shown in red)(Shepherd 2013)

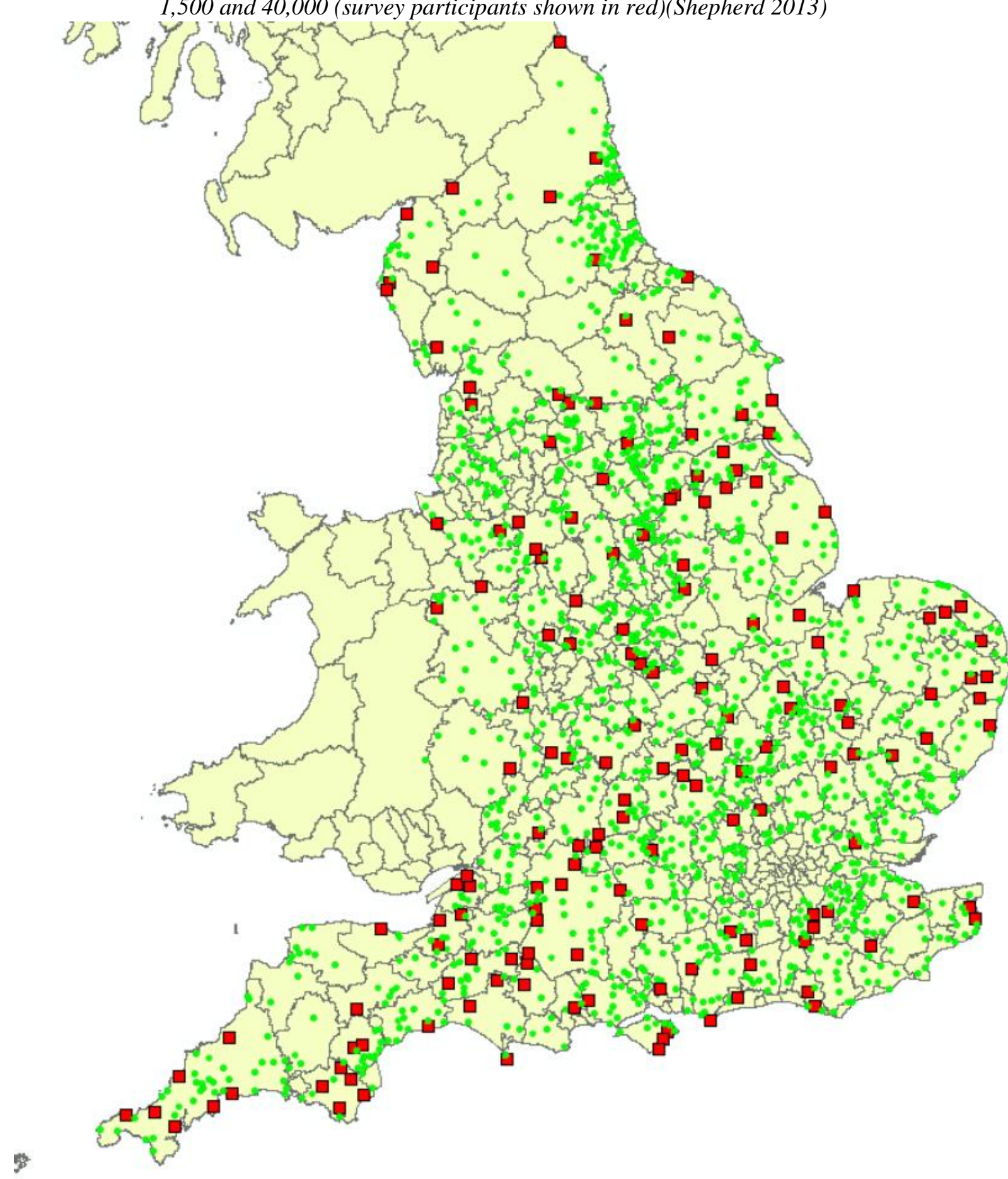

There is no obvious pattern in terms of participation/non-participation in the MTI. The response broadly reflects the number of towns in each band, up to a population of about 30,000. As the MTI was designed with smaller towns in mind, this is to be expected. 


\section{Results}

\section{Reasons given for not responding to the main survey}

Before discussing the results of the main survey, the answers to the second, 'non-responders', survey are considered. Although not central to the main aims of the research, the reasons given (summarised in Figure 4) are of interest in terms of understanding the day-to-day pressures faced by clerks.

Figure 4: Reasons given for non-response to main survey by 50 clerks

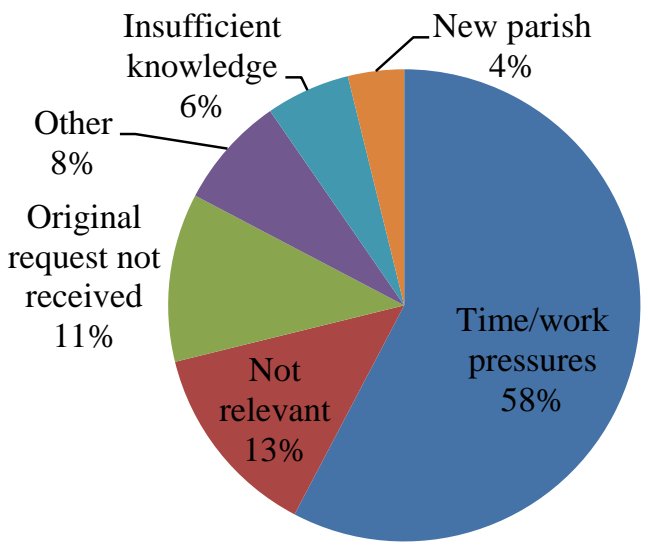

Some 31 of the 53 respondents referred to a lack of time, and/or pressure of work. One clerk wrote, 'currently working over 50 hours per week as do other members of my staff. Filling in surveys is not a priority', whilst another stated that, as a part-time worker, it was only possible to deal with 'day to day issues'.

Seven clerks stated that the survey was not relevant to their authority. For example, and perhaps because of the prominence of the MTI as the first item in the questionnaire, three clerks emphasised that their parishes were villages, not towns; hence their belief that the survey was irrelevant. This is interesting for two reasons. Firstly, given that the programmes covered by the survey were from the rural white paper, and that villages, the most (stereo) typical rural settlements, had their own RWP programme (VV), the survey was relevant. Secondly, although obviously unbeknown to the clerks, all three of these villages participated in the MTI. These responses indicate both how short institutional memories' can be, both in terms of the work that the councils were, presumably, involved in, and, more generally, clerks' knowledge of the white paper's existence. It also suggests that any impacts the programmes might have had on these particular settlements were either minimal, outside the councils' spheres of influence or interest, or simply that the council was not involved, or that the clerk, and possibly councillors, were not in post at the time (or that the clerk did not read the whole of the questionnaire). 
Similarly, but from a town, rather than a village, a clerk wrote that the survey did not apply, '... to my town council's circumstances as it not considered to be rural, but urban?' (sic). That this town, a very long-established market town and rural service centre with a population of about 25,000 , took part in a regional programme that was closely related to the MTI, is indicative, not only of the lack of knowledge of involvement in RWP 2000 programmes, but also of some confusion about urban-rural definitions, and the town's place in the settlement hierarchy. This example also reveals the potential of multiple programmes, which although relatively well-integrated and understood by the officials administering them, are sufficiently different, short-term, and remote from the day to day priorities of busy town clerks to confuse, and, possibly, frustrate them.

Other reasons given for non-response also hint at the rapidity with which programmes can quickly be lost in the "noise" created by reorganizations, changing priorities, day to day work, and changes in staff and council membership. One response sums this up effectively, and succinctly, 'New clerk, new councillors - lack of knowledge', whilst another made some telling points in an email to the writer:

Local Councils are regularly exhorted to reduce the paperwork as soon as it is legally permitted ... [and this leads] ... to a flurry of shredding whenever there is a change of Clerk ... Some of the first things to go are documents relating to programmes which the Council may have considered, but didn't see any benefit from, followed by those which are now over. And lots of documentation has been stored in various places in media which may no longer be easily retrievable ... [e.g. floppy disks].

It is both daunting and frustrating to look at a list of programmes which might have been of benefit, and to think - why weren't we involved (except for lack of time)?

Lack of time to fill in the questionnaire properly - there are never slack periods, there are busy times, there are frantically busy times, and there are times when all you can do is react to the most urgent business that comes across your desk. It is now August, and in theory we are in semi-recess - I have 6 meetings here this month, and 3 'outside'.

A questionnaire in June, when we are all getting our audits finalised, is unlikely to receive a high priority.

Wariness about what the results may be used for - is there a hidden agenda, is it going to create more work for the towns and Parishes ... Localism and Big Society sound all well and good until you look at the (financial) numbers, and until you work out that there isn't always a pool of recently retired bank managers, teachers and craftsmen etc. ready and with time to get involved with applying for Lottery Funding and making a positive difference in their community or neighbourhood - but to say this is perceived as being negative.

It is reasonable to assume that the majority of clerks face similar time, staff, and financial pressures to those described above. When coupled with annual budgeting and a four-yearly electoral cycle, it is hardly surprising that recognition of the programmes and, indeed, of the white paper, in this everchanging political and policy landscape, is relatively low. The results of the main survey discussed in the next section reflect these realities. 


\section{The main survey - findings}

\section{The programme-related questions}

Figure 5 summarises the responses in relation to each of the programme-related questions.

Figure 5: Summary of findings from main survey illustrating involvement in programmes by responses

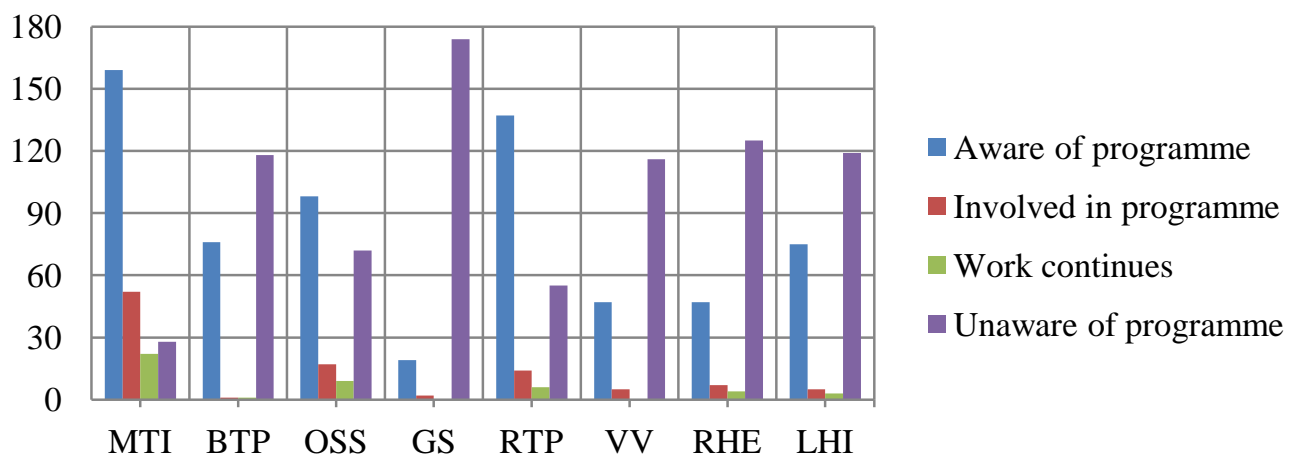

The data illustrate that, amongst the 193 clerks whose responses were analysed, programme-related recognition, is low. Indeed, with the exceptions of the MTI, OSS and the RTP, the majority of respondents were unaware of the programmes, although, taken overall, the number of clerks aware of the programmes is large relative to the number whose towns were involved in them. The fact that work continues in only a few towns suggests that work has been difficult to sustain, or, to take a more optimistic view, has been completed. Comments made by 76 clerks suggest that both explanations apply.

Views include frustrations with higher tier authorities, such as:

Our [District Council] have struggled (I think) to understand the opportunities that Localism offers. We are VERY proactive and want to engage with all our partners. Our One Stop Shop that the DC were considering closing - now is in fantastic shape.

Regarding the Youth services, encountered heavy handed approach from District Council ... only huge pressure from all agencies of the town forced the DC to back down.

There are also more positive views, for example, acknowledgements that,

We work with the District/County Council ...; that, our District Council ... is proactive ...; and that the, Town Partnership [is] currently funded by ... District Council.

In a comment specific to the MTI, a clerk involved with the programme in 2001, noted that,

a lot of people put a lot of effort into it but were not given sufficient, or the right kind of, support; that the ... [unitary] Council ... claimed it should be a 'bottom up' exercise when in fact it was the exact opposite and they tried to control everything; and that [the Regional Development Agency] did not help matters by their incredibly bureaucratic approach and their propensity for moving the goalposts. 
Frustrations in two cases extend to councillors:

The Council's Executive going back on decisions. Unfortunately a number of our councillors do not wish to move into the $21^{\text {st }}$ century, and therefore decline opportunities

Other frustrations are associated with programmes. For example,

Regrettably ... experience with the ... MTI and the subsequent ... Beacon Town Forum, was that the main beneficiaries were the consultants which each project was expected to commission in order to prove [project feasibility]. ... on spending thousands on Consultants Reports, the three years were up, the staff put in place to steer each projects were released, and the volunteers who had worked extremely hard ... were left with little or no support ... . Funding ... dried up, enthusiasm waned, and 13 years on these projects are no further forward. This has left ... volunteers entirely disillusioned.

Similarly,

Over the years, my councillors have felt that a lot of these initiatives from central government have been the result of the need to be seen to be doing something, to be seen to be very busy being busy, without really understanding the problems it is trying to solve, and thus tailoring the initiatives accordingly.

This clerk also made the following point about towns councils' long-standing disappointments with the reforms to local government that took place in the 1970s:

The 1972 LGA [Local Government Act] emasculated a lot of town and parish councils, by shifting power and responsibility and resources to the new district councils, and the Government is not going to quickly change the attitude of 40 years that it's always someone other council's (sic) responsibility to do things. I have an uphill struggle!

A perceived lack of local influence over planning decisions is evident from this quotation,

We have had joint Strategy meetings with surrounding Councillors to try to stop building developments .... Of the four we have objected to three have been granted planning permission.

Another clerk expressed reservations about partnerships and local government reform, whilst acknowledging that recent developments around "Localism" give cause for hope:

Partnership' is a vague concept, a fig leaf for Whitehall to cover the atomisation of local services, schools, colleges, career services etc. into many separate organisations by Whitehall over the last 40 years since 1974. It seems to mainly mean talk shops between the organisations that used to be part of the local authority, trying to get something for nothing. Only the very recent Localism Act has given us any real power to do things, and is welcome. We are however active in the Town Centre Partnership and BID [Business Improvement District] Company which is a partnership with town centre businesses.

In all, fifteen clerks stated that partnerships, formal and informal, are working well. In one case a distinction is made between local informal partnerships, described as,

hugely rewarding and successful. , and others that, have not been so successful or have petered out such as MTI. Others have ploughed their own furrow, in that, we haven't been actively involved in any of the programmes listed so we have just carried on. 


\section{Response to the survey}

Overall, analysis of the data, town by town, illustrates a low response to the survey from programme participants. This is discussed in the next section, taking each programme in turn.

Only 76 of the 233 MTI towns surveyed responded, and only 52 of these knew that their town had been involved in the programme (similarly, of the 27 clerks who said they were unaware of the MTI, five are from MTI towns). Of the 52, nineteen were not recorded as participants by the British government in 2004 (Hansard 2004). Some of these towns, however, were involved regionally, rather than nationally, and may well have continued their work, or even become involved, after the MTI officially closed in 2005. In fact, towns not formally involved in any of the programmes may, with local support, have followed individual paths. The Healthcheck, the MTI's community audit guidance document, was freely available online, and so could be used by any group, in any settlement, anywhere with internet access; albeit without the human and financial support available to towns that took part in the official programme.

Six of the towns in which work continues are working with Action for Market Towns ${ }^{1}$, the membership organisation to which the then Countryside Agency bequeathed the MTI process, and which now provides support services to town partnerships. Five other respondents referred to specific projects, such as markets, improved signage, '.. the development of a community hub and other initiatives ...', to non-specified, but continuing work led by the town partnerships.

That only eight of the 18 Beacon Towns completed the survey questionnaire is surprising given the programme's relative prominence as part of the MTI. The award of BT status to each of the towns was well publicised locally (BBC 2004), the work in the towns was recorded (Nichols 2005), the partnerships were awarded $£ 3,000$ annually, to help them help others, and in 2004 an international conference and series of study visits was organised around the programme for the wider benefit of country towns (AMT 2004). Interestingly:

- only one of the clerks from the eight towns knew that their town had BT status, noting that although work continues, the town's BT forum is, 'Currently dormant - but not yet dead ...', due to a lack of, '... funding pots'. (ie money);

- the one town listed as involved was neither a BT, nor an MTI town. The clerk appears to have been referring to the beacon lit in the parish to celebrate Queen Elizabeth's 2012 Diamond Jubilee $^{2}$, noting only that involvement had been 'successful'. Similarly, the clerk from an MTI town who indicated awareness of the programme, asked 'We lit a beacon for the Diamond Jubilee, is this the project in question?' This illustrates how easily confusion can arise when programmes have similar names (during the period covered by the RWP 2000 programmes the term, Beacon, was also applied to schools and councils).

\footnotetext{
${ }^{1}$ www.towns.org.uk

2 www.thediamondjubilee.org/diamond-jubilee-beacons
} 
Turning to One Stop Shops, only two clerks from the seven towns surveyed that featured in the Countryside Agency's good practice handbook (CA 2003a: 4) responded. One, from an MTI town, recognised its involvement. The other knew of the programme, but was unaware of the town's involvement. In all, 98 respondents indicated that they knew about OSSs. Of these, seventeen said that they were involved. As an example of the importance of the need for careful analysis of survey data, one respondent recorded that they were aware, that their town was involved, indeed that work continued, and ... they were also unaware!

Of the nine towns in which work is said to continue, none featured in the Countryside Agency's handbook (CA 2003a). OSSs have, however, existed for a long time. For example, in Cornwall, where the council has $23^{3}$, recognition and involvement are to be expected.

Unlike OSSs, Gateway Stations were linked to MTI towns. The programme developed from work done by the Countryside Agency (CA 2001). All 13 of the MTI partnerships involved were surveyed, but only six responded. Of these, one clerk was aware of the programme, but was unaware that the town had been involved. Another had been involved in the programme in a previous job. A clerk from another town not involved with the programme noted that the council had recently, '... opened one ... in partnership ...' with the county council, although no details of the scheme/station were given.

The GS work was supported financially, in part, from the Rural Transport Partnership budget. The RTP began in 1998, and was promoted in RWP 2000. Therefore, a high level of recognition is to be expected. More surprising is that work continues in only a few places. This is disappointing because,

The UK has been at the forefront of experimentation in rural transport provision over the past two decades (via initiatives such as the Rural Transport Partnership, Rural Bus Challenge, (James and Waldron $2010 \mathrm{p} 16)$.

The RTP ended in 2005, and so work has also largely ended. One clerk noted that the programme closed when the funding was withdrawn'. Other comments show, once again, how quickly things are forgotten, 'Not sure why we are not involved ...' (note the present tense), and 'I am a new town clerk ... I have not heard of this'.

Nevertheless, some work continues. One clerk's council is, 'working with Government/Local Authorities/Bus/Rail and community transport groups for improved services', whilst another's continues, '... to support [a] local initiative'.' Also, guidance, if not money, relating to community transport is still available from rural community councils (Northants ACRE 2013).

\footnotetext{
${ }^{3}$ www.cornwall.gov.uk/council-and-democracy/contacting-the-council/one-stop-shops/?page=2106
} 
The RTP was part of the Vital Villages programme (Butcher 2010). Although one clerk noted that the council used the VV programme to gain access to money for a transport project, the source of the grant, RTP or Parish Transport, was not specified. Five clerks recorded that their towns were involved in the programme, but only one provided details, stating that the '... Town Plan was published in 2006 as a result of the Vital Villages Initiative'. Another noted that the council 'did look into participating in this [but] considered there would be too much additional work ... to create a Parish Plan. However, Town Council did develop a Parish Directory (without funding assistance) in 2006 and a Community Plan in 2012 did have some elements from the Vital Villages process'. The connection between VV planning work of 2006 and the 2012 community plan suggests that the programme has left a useful legacy.

None of the survey respondents suggest that VV or MTI plans have been formally adopted into the planning system, as was originally hoped. Plans have been adopted (New Milton 2012), but not everywhere (Chiltern DC 2012: 4). It is possible that the level of awareness and acceptance of both approaches would be greater today if their status as supplementary planning guidance had been statutory. The present British government's broadly similar approach, Neighbourhood Planning (PP 2011), has statutory authority (Chiltern DC 2012: 5), and, '...introduced new rights and powers to allow local communities to shape new development... '.

No mention was made of the Community Services Grant.

The term, Rural Housing Enablers, was only recognised by 47 respondents (compared with 135 who were unaware). Central government support for RHEs ended in 2008, when funding and responsibilities were devolved to local authorities and housing associations, with the result that a once national scheme fragmented. As the author of a review of RHE work in England and Wales wrote, '... although some [RHE] posts have been re-established, continuity in terms of individuals in post has been disrupted, as people leave to seek more secure job prospects'. (Scottish Government 2009). Therefore, the low level of awareness is to be expected. It is, nevertheless, also surprising, given the long-standing importance attached to rural housing (RDC 1993, UK Parliament 2013), and the stated belief of one RHE, in regard to the continuing need for affordable rural housing, that, 'One thing is for sure though, the demand is still there!' (Kersley 2013). Although, according to Kersley, there are 38 RHEs still in post and training is provided, nevertheless, '..posts are constantly under threat because of cost cutting by funders'. (ACRE 2013). 
The survey revealed some involvement with affordable housing and related projects. Of the 14 clerks who commented, one referred to a recently completed housing survey, another that some homes had been built, whilst a third noted that, although no land was available, an affordable housing project was '... on going ...'. Two others reported that their councils were working with rural community councils, and also, in one case, with the local Borough Council '... to identify suitable sites for small developments'. In the second case the council was '... very actively engaged ...' as a consultee in development of a Local Plan.

Finally, we turn to the Local Heritage Initiative. This scheme ended in 2006, and was aimed at community groups, not councils. Today, very similar projects to those supported via the LHI continue to be developed and implemented under the auspices of the Heritage Lottery Fund ${ }^{4}$. It is not known if clerks are aware of current HLF schemes, but it is likely that they are, because councils are eligible (HLF 2013), and this probably helps to explain the relatively high level of awareness.
Figure 6: Total across all programmes, of survey question answers

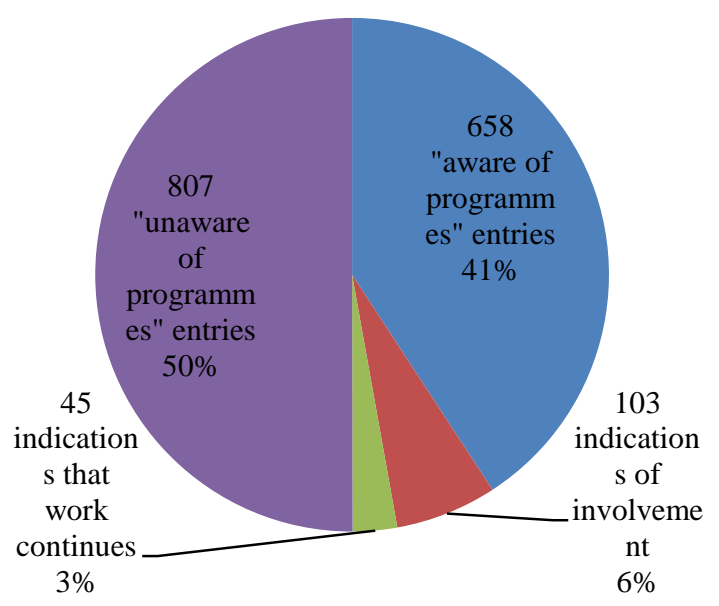

To conclude, when the respondents' answers to each of the questions are added together (Figure 6), overall, unawareness exceeds awareness, and the number indicating involvement with the programmes is small. In view of this, the even smaller number indicating that work continues is to be expected. The remaining data gathered from the survey will now be considered.

\footnotetext{
${ }^{4}$ http://tinyurl.com/33u7yb5
} 


\section{Town councils' membership of organisations, and acquired responsibilities}

Respondents were asked to indicate whether their council was, or had ever, belonged to Action for Market Towns, the Historic Towns Forum, the Association of Town Centre Management, and the National Association of Local Councils. All of these organisations exist to provide various support services, be they to councils, or more widely, for example, to interest groups and business sectors. The answers given are summarised in Figure 7.
Figure 7: Councils' involvement with membership organizations $\quad$ (by number of councils in each category)

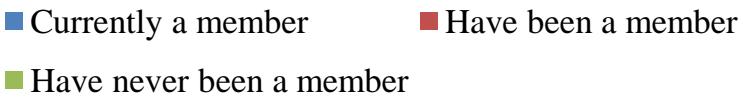

182

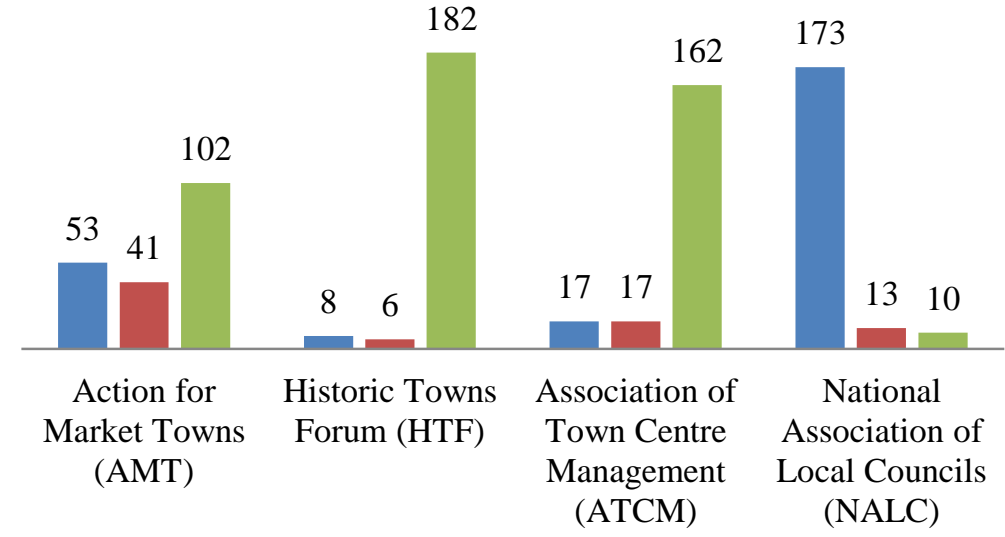

As the National Association of Local Councils (NALC) was set up in 1947 (Stevens 2006: 114-115) specifically to support town and parish councils, relatively high membership is to be expected. Compared to the other organisations it is effective at retaining members. The low membership numbers for AMT, HTF and ATCM, relative to NALC, and the broadly comparable relationship between their current and lapsed membership numbers, is interesting. Their services, although not council specific, are, to judge from their names, relevant to councils, especially given concerns about the viability of towns as service centres, and the need to maintain the characters and identities of these often historic places.

Although beyond the scope of this paper, the question of how best to provide external support to towns, something which, for example, the MTI attempted to do, is worth investigating.

It may be, however, that town councils are instinctively wary of external support, or at least externally-directed support. One clerk wrote of, '... a perception that towns may have been 'used' as a front, whilst the principal authority accessed funding to pay to retain their own staff in sometimes nominal support of the programmes'. Of course, realpolitik will always intrude, for example, 'Our general experience of localism is that the cash-strapped principal authority is keen to dispose of liabilities, but very reluctant to release assets.', and, '[We are] trying to work with ... Council, but communication is very difficult'. Other clerks, however, reported good relationships with higher tier authorities. 
There is evidence of a desire for autonomy, and a willingness to take responsibility for local action. This is clear from the information in Figure 8, which illustrates clerks' preferences for central government policies designed for local implementation.

Figure 8: Number of Councils Involved in Work Related to Various National Policy Initiatives

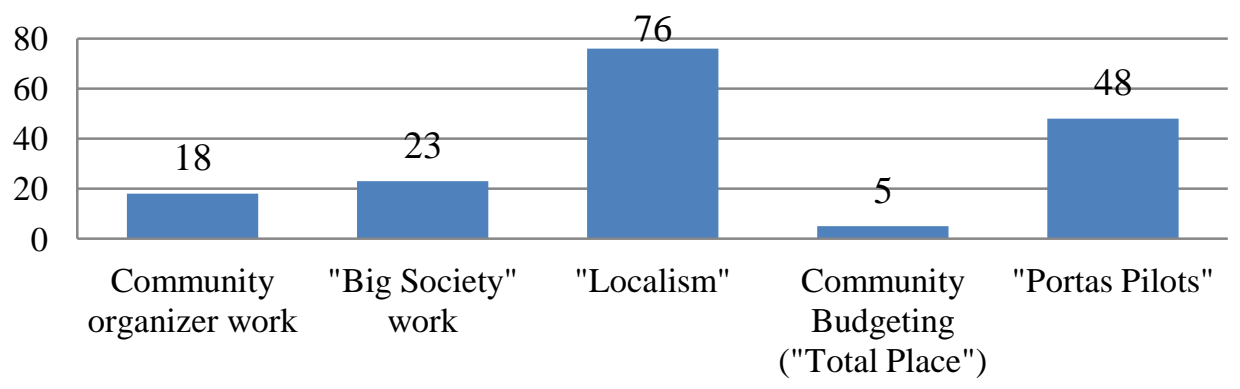

There is also involvement in Community Organiser and 'Big Society' work. These are related, in that the community organiser training developed as part of the 'Big Society' movement. Organisers, having completed a training course 5 are in a position to help "Big Society" work (Cameron 2011). Both of these are essentially community development 'tools', as is the 'Portas Pilots' scheme, a politically-inspired (DCLG 2012), retail consultant-led, and contested (Channel 4 News 2013) competition designed to create, '... High Streets of the future ...[that are] ... multi-functional and social places bustling with people, services and jobs which offer a clear and compelling purpose and experience that's not available elsewhere, and which meets the interests and needs of the local people’. (Shapps 2012: 4).

Only five clerks reported involvement with community budgeting, '... a concept that gives local public service partners the freedom to work together to redesign services around the needs of citizens, improving outcomes, reducing duplication and waste'. (LGA 2012). Although it appears to have evolved to the point where something called a Public Service Transformation Network (PSTN) is needed to, '... spread innovation from the Whole-Place Community Budget pilots and What Works Centres to ... provide advice and support on co-designing local public service transformation'. (NESTA 2013), none of the respondents referred specifically to community budgeting. This may be because of the emphasis on public service integration, '... mainly in the fields of families with complex needs; health and social care for adults; economic growth, work and skills; reducing reoffending and domestic abuse; and early years'. (Wintour 2013). As these are primarily the responsibilities of higher tier local authorities, they are unlikely to involve town councils.

\footnotetext{
${ }^{5}$ www.cocollaborative.org.uk/about-community-organisers
} 
According to NESTA (2013) the purpose of the PSTN, the creation of central government, is to, ' $\ldots$ drive the transformation of local public services ...' (writer's emphases), wording which seems to suggest that 'localism', despite the fact that the LGA supports the PSTN (Wintour 2013), has limits where local determination of needs and priorities is concerned.

One of the five responding clerks referred to participatory budgeting. This differs from community budgeting, which, with local authority budgets being cut (LGA 2013), and as hinted at in the previous paragraph, has more than a whiff of 'top down' pressure, whereas participatory budgeting directly involves local people in determining spending priorities. Although the clerk did not elaborate on the effectiveness of the council's scheme, described as a "pilot" (ie a trial), the approach is communityled. Another council asked residents to suggest how to spend a specified sum of money. The suggestions were voted on, again by all residents. According to the clerk involved, this was a, 'Very illuminating, but time consuming experience! Not repeated by members ... ’.

Other clerks also provided evidence of councils' work-related ambition, enthusiasm and initiative. Examples include: employment of staff, such as an economic development officer and 'lengthsmen', youth provision, maintenance of recreational grounds and parkland, street cleaning, running community buildings, libraries, a lunch club, cemeteries, a community greenhouse, tourist information, and public conveniences. One council has appointed, '... students as advisors who attend committees and working parties. They give advice to councillors on all matters ... in particular how issues affect young people. We currently have 20 student advisors which is more than we have councillors!'

Further evidence of ambition and pride comes from one council's economic development plan. The council runs an arts centre that was previously the responsibility of the district council. The centre, which houses a theatre and a two screen cinema benefits from the help of 200 volunteers, and attracts 300,000 visitors annually. The council also runs a job club, a youth café, a business awards scheme and a yearly business show, as well as the more usual investments in Christmas lighting, floral displays, and festivals. It is an example of the 'Big Society' in action. Of course, volunteering is not new, and it would be remiss to note this encouraging, impressive example of self-help without emphasizing that volunteers with the necessary time, skills and freedom of choice are more likely to be found in relatively affluent places than in poorer ones. There is still a need, therefore, to help improve the lot of disadvantaged towns; for example, by sharing experiences and expertise, and by providing practical help from professionals, such as youth and community development workers. 
Three comments reflect irritation and scepticism with the idea that 'Localism' and the 'Big Society' are new concepts: 'We are somewhat sceptical about the 'Big Society'. Volunteering is a big feature of our town and ... success will not stand or fail with glib attempts at branding, especially when the general population sees the Big Society as a smokescreen for local government cuts ... '; 'A lot of what we do was 'Big Society' before 'Big Society' existed ... '; 'In terms of the localism agenda and 'Big Society' - if you mean delivering projects to meet local needs, this is what we have always done and will always do'.

The last two questions relate to the existence of foodbanks and councils' status and intentions regarding the Quality Parish Council scheme. The topics are not connected, but are discussed together, and briefly, because, in both cases, the data do not allow for detailed analysis.

\section{Foodbanks}

None of the towns had a

Figure 9: Growth in the number of foodbanks in towns foodbank five, or ten, years ago. The reasons for this change are beyond the scope of this study, but it is hoped that the information obtained (Figure 9) will add to the debate, and stimulate. Clerks' comments refer to joint working between

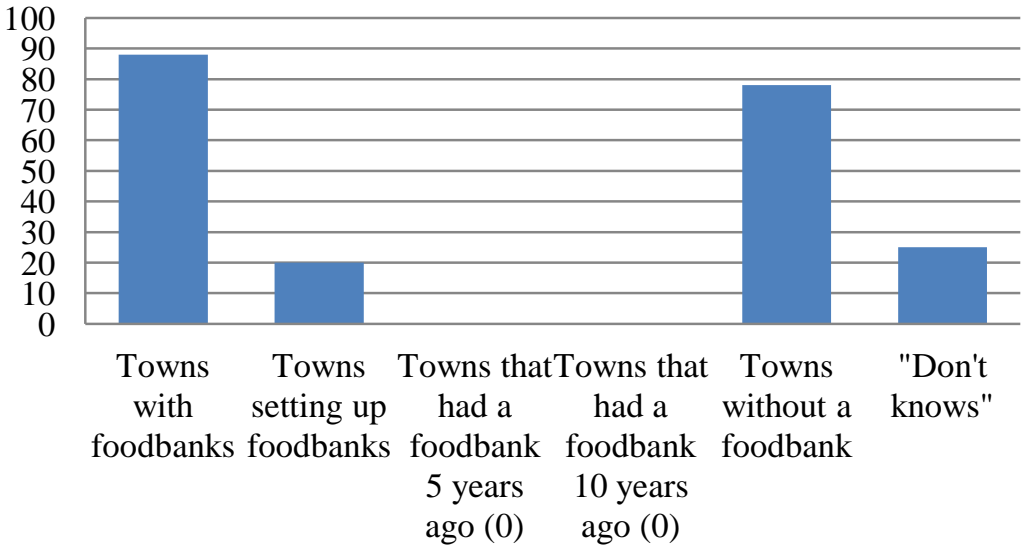
towns, the existence of more than one foodbank in some towns, the adoption of a foodbank as a mayoral charity, and the close involvement of churches, the Salvation Army, and other local groups in the provision and management of foodbanks. 


\section{Quality parish council status}

The differences in involvement in activities, membership of organisations, Figure 10: Summary of survey results illustrating the differences between councils with \& without Quality Status in terms of programme awareness, involvement \& membership of organization and awareness of programmes between Quality Parish Councils and non-QPC towns are noticeable (Figure 10), in that, overall, QPC towns 'score' more highly. However, these data should be treated with caution, not least because the number of councils with quality status is small. It is not possible, for example, based on the information provided by clerks, to explain why more QPC towns have foodbanks than non-QPC towns. There is no obvious correlation to be drawn between towns of either status and the existence of a foodbank, especially as foodbanks are usually managed by charities, not by councils. Nevertheless, given the differences evident in Figure 10, it would be interesting to know if town councils with quality status are more proactive, or "connected" to their towns, than those without QPC status.

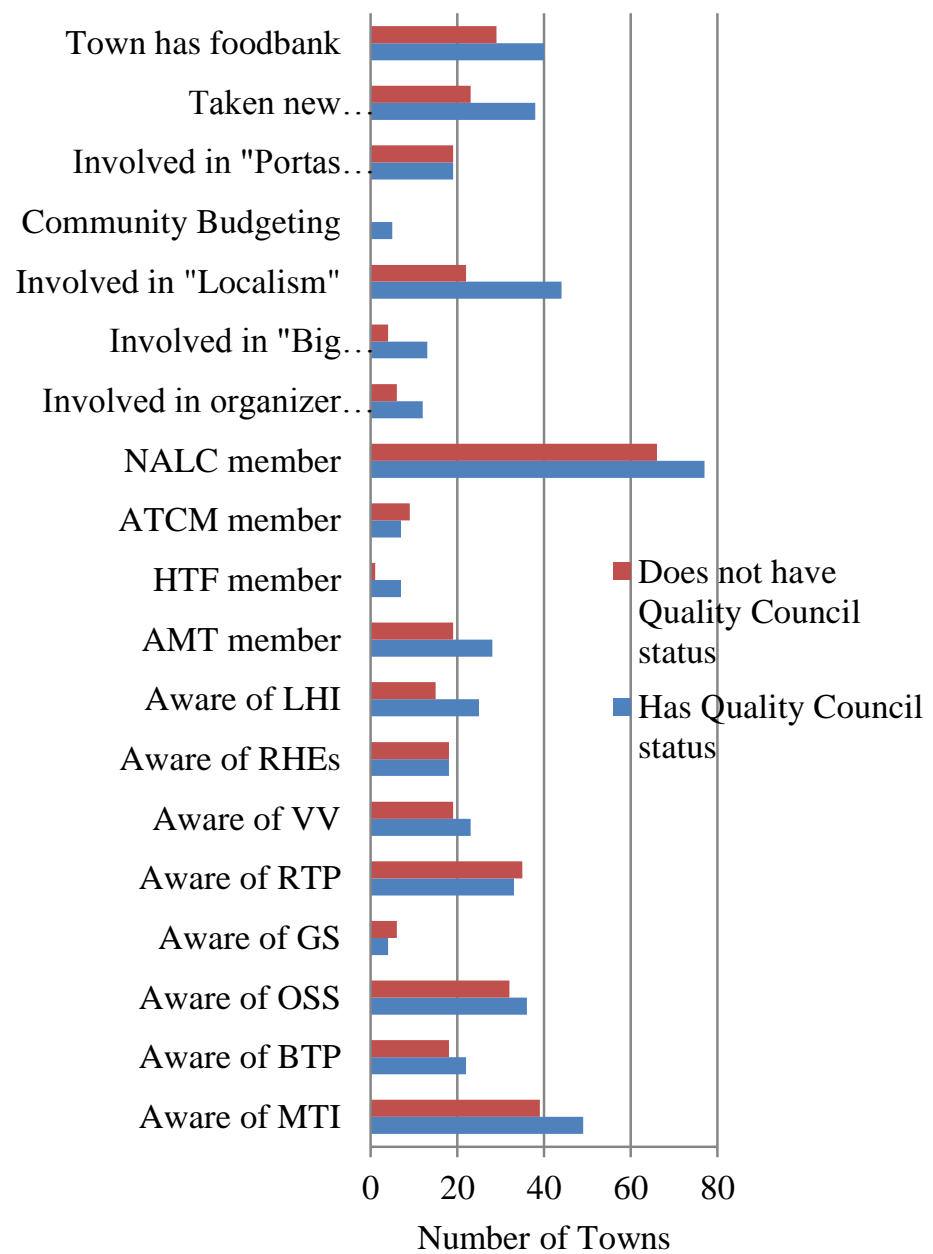

Some comments made by clerks suggest a degree of scepticism about QPC status, with several referring to uncertainties arising from the scheme's current state of suspension (NALC 2012). Eighteen clerks explained that their councils had not reapplied. Reasons given include a lack of obvious benefits, additional work, and, in one case the belief that, '... the lack of quality status has not precluded us from doing anything we wanted/needed to do', a sentiment shared by others. 


\section{Conclusions}

The RWP 2000 programmes are not widely remembered by the nearly 200 clerks who responded to the survey. At this distance, some fourteen years after the Rural White Paper was published, and nine years since the work started to draw to a close, it is difficult to know what remains, and to what extent current activity has been influenced and informed by the programmes. There are legacies, for example work related to transport such as Wheels to Work schemes ${ }^{6}$, community development (parish plans, neighbourhood planning, AMT's Towns Alive programme), and housing schemes assisted by RHEs (WDDC 2012: 1), but knowledge of their origins is limited amongst the respondents.

At one level, perhaps, this collective loss of memory does not matter. Work similar to, and probably descended from, the programmes continues. What has been lost, however, and what surely must matter, is that the work has become individualised. The sharing of experience and information - ie learning for mutual benefit - that was central to much of the RWP 2000 work, and that was facilitated nationally and regionally by the now abolished Countryside Agency and regional development agencies, no longer takes place.

A lot of public money and volunteer effort was invested in the programmes, but there was little in the way of formal monitoring and evaluation, and so it is difficult to judge overall effectiveness. The failure to ensure that experience was shared, and good practice developed and encouraged for longterm implementation, albeit at a lower level of activity and expenditure, in order to avoid costly duplication and eventual reinvention of wheels, represents poor value for money and a wasted opportunity.

It is disheartening for officials such as town clerks when relatively major work programmes, in which their involvement is heavily encouraged, are introduced, only to cease, all too predictably, within a few years. It is little wonder that some of them look backwards to the pre-1972 structures, and forward to more autonomy. To judge from the examples given of work that councils are doing, it seems likely that are capable of doing more, and would welcome the opportunity to do more, and the necessary freedoms to allow them to do it.

\footnotetext{
${ }^{6}$ www.wheels2workassociation.org/about.php
} 
Although there is some recognition of these authorities' potential to lead and innovate (NALC 2010, NEF 2005, Towns Alive 2013), the omens are not good. Almost in parallel with the RWP 2000 work, the rhetoric around devolution from national politicians and lobby groups has centred on 'communities'. Quite what is meant by the word, 'communities', is unclear, except in one regard: it is not synonymous with 'elected council'. As Clements noted (2008 p170), ‘.. central government, apparently eager to hand more power to the people, regards local authorities as unworthy representatives, more an obstacle to passing on that power to communities'. Central government should, perhaps, look first to itself, as disaffection with national politics (Guardian/ICM 2013) and, 'The great fear that grips democratic electorates - that globalised markets will once again run out of control ...' (Ignatieff 2014) suggests that there is a need to rebuild trust, and to strengthen democracy.

Where better - indeed, where else - to start, than the truly local?

It would be wrong to make too much of the survey discussed in this paper. On the other hand, the information provided by the clerks is real. Their frustrations and pride in achievements are evident, deserve to be noted, and invite further investigation; not least because, as Barnet and Sweeting note (2013 p11), although, 'It would be over-stating the case to say that parish and town councils are always ignored by scholars of local government ... they tend to be overlooked, discounted, or relegated to footnotes'.

Finally, there are some who would find in the results of this survey reasons to oppose future work of the kind introduced by RWP 2000. There are other who would argue that, if reduced, but consistent, support had been continued, with the intention of passing increased responsibility and power to town councils, their involvement and commitment would have been greater, much more would have been achieved, and participatory democracy strengthened. Which of these views is right, we are, given our inability to take a consistent, long-term approach, unlikely to find out. We should, however, try. 


\section{Appendix 1}

\section{The programmes and related activities included in the survey}

The eight programmes, embracing community development in towns and villages, transport, housing, and local heritage, are outlined below.

Market Towns Initiative (MTI) - a $£ 37$ million programme aimed primarily at towns in priority areas with populations between 2,000 and 20,000. Its purpose was to help local people assess their town's strengths and weaknesses, and then to plan and implement projects designed to, "... help create new job opportunities, new workspace, restored high streets, improved amenities ... transport facilities and help with community needs." in around 100 towns (DETR-MAFF 2000 p75).

Beacon Towns Programme (BTP) - related to the MTI, eighteen towns were selected, “... to demonstrate the range of different problems and challenges which market towns experience and from which other towns can learn. " (DETR-MAFF 2000 p75, Nichols 2005).

One-Stop Shops (OSS) - already an established concept, supported by RWP 2000, especially in relation to health (DETR-MAFF 2000 pp33-34), and business support (p129). For its part, the Countryside Agency published a good practice handbook featuring case studies from eight towns, five of which had MTI partnerships (CA 2003 p4).

Gateway Stations (GS) - a two-year programme that enabled thirteen MTI towns to make the most of their railway stations, in order to improve, integrate, and encourage the use of, local transport services, both for the benefit of the towns involved, and as exemplars for other towns (Nichols 2005a p5).

Vital Villages (VV) - The programme comprised four schemes: Community Service Grants, aimed primarily at supporting shops and pubs; Parish Plans, similar to MTI Healthchecks (community-led plans in the current parlance); Parish Transport Scheme grants, designed to help those without access to private transport by, e.g., subsided moped hire (SRYP 2013); and, the Rural Transport Programme (see below).

Rural Transport Partnerships (RTP) - a $£ 12$ million programme (DETR-MAFF 2000 p55) used to support local transport partnerships and projects in towns and villages throughout rural England. The partnerships employed specialist officers, designed and implemented projects, and were able, amongst other things, to cover project start-up and improvement costs (CA 2003 p76).

Rural Housing Enablers (RHE) - established in England in 1991 (JRF 1995 p2) to help increase the number of affordable homes, their importance was recognised in RWP 2000 (DETR-MAFF 2000 p50).

Local Heritage Initiative (LHI) - “... a national grant scheme, funded by [the] Heritage Lottery Fund, that helps local groups to investigate, explain and care for their local landscape, landmarks, traditions and culture ... " (CA 2003 p77). This stand-alone programme ran from 2000 until 2006, resulted in approximately 1,400 projects, and was well suited to MTI and VV community-led development work. 


\section{References}

ACRE. 2013. Rural Housing Enablers. Action with Communities in Rural England, Cirencester, Gloucestershire, UK Available at: <http://tinyurl.com/oggpf5f>. Accessed: 23 December 2013.

AMT. 2004. Celebration. Market Towns Week, May $3^{\text {rd }}-7^{\text {th }}$, 2004. Action for Market Towns, Bury St. Edmunds, Suffolk, UK.

AMT. 2005. Market Towns Healthcheck Handbook. Action for Market Towns, Bury St. Edmunds, Suffolk, UK.

Barnett, N., and Sweeting, D. 2013. Is UK local government really so big? Paper presented at the Policy \& Politics conference, September 17-18 2013, Bristol: 'Transforming Policy \& Politics: The Future of the State in the 21st Century'

BBC. 2004. Town shines a beacon for business. Available at: 〈http://tinyurl.com/71mjf8s>. Accessed: 19 December 2012.

Butcher, L. 2010. Transport: rural areas. House of Commons Library Note SN/BT/365, UK Parliament. Available at: <http://tinyurl.com/pdbfdkj>. Accessed: 20 December 2013.

CA. 2001. "Trains for Market Towns: Making the links with regeneration, sustainability and social inclusion”. Association of Community Rail partnerships, Huddersfield, UK. pp66.

CA. 2003. Setting up One Stop Shops - a good practice handbook on linking services in market towns. The Countryside Agency, Cheltenham, Gloucestershire. pp77.

CA. 2004. Assessment of the Market Towns Initiative: a Summary. The Countryside Agency, Cheltenham, UK. pp24.

CA. 2004a. The Role of Rural Settlements as Service Centres. The Countryside Agency (later Commission for Rural Communities), Cheltenham, Gloucestershire.

Cameron D. 2011. Leadership for a better Britain. (speech). Available at: 〈http://tinyurl.com/d6nndgg>. Accessed: 22 November 2013

Clements, D. 2008. Parish Pump Politics. In: Clements, D., Donald, A., Earnshaw, M., and Williams, A., The Future of Community (reports of a death greatly exaggerated), Pluto Press, London.

Channel 4 News. 2013. Mary Portas hits back at Grimsey over high street report. Available at: <http://tinyurl.com/nbr53nw >. Accessed: 13 March 2014.

Chiltern DC. 2012. Thinking of preparing a Community Led Plan? DRAFT. Chilton District Council, Amersham, Bucks. UK. Available at: <http://tinyurl.com/ovlu433>. Accessed: 10 January 2013.

CRC. 200?. Rural Communities Best Practice Database. Available at: 〈http://tinyurl.com/ndmoh2f >. Accessed: 09 December 2013.

Cribb, J., Joyce, R., and Phillip, D. 2012. Living standards, poverty and inequality in the UK: 2012. Institute of Fiscal Studies, London. Available at: <http://tinyurl.com/ovju3w9 >. Accessed: 09 January 2014.

DCLG. 2012. Portas Pilots Prospectus: an invitation to become a Town Team. Department for Communities and Local Government, Bressenden Place, London. pp17.

Defra. 2004. Review of the Rural White Paper, Our countryside: the future. Product Code PB8662. Department for Environment, Food and Rural Affairs, Nobel House, Smith Square, London, UK. pp94.

DETR-MAFF. 2000. Our Countryside: The Future. A fair deal for rural England (Cm 4909). The Stationery Office, Norwich, UK. pp176.

DoE-MAFF. 1995. Rural England. A Nation Committed to a Living Countryside. HMSO Publication Centre, London. pp146.

Ekosgen. 2009. Evaluation of the Market Towns Initiative. ekosgen, Sheffield, Yorkshire, UK. pp75.

Ellwood, S., Nutley, S., Tricker, M., and Waterson, P. 1992. Parish and Town Councils in England: a Survey. Her Majesty's Stationery Office, London.

Guardian/ICM. 2013. Fury with MPs is main reason for not voting - poll. The Guardian, 26 December 2013. Available at: < http://tinyurl.com/pvnnkqw>. Accessed: 09 January 2014. 
Genecon. 2010. Evaluation of the Renaissance Market Towns Programme. Final Report, March 2010. Genecon Economic and Spatial Regeneration, Leeds, UK. Available at: <http://tinyurl.com/p968sfp>. Accessed: 03 January 2014.

Greene, M. 2007. Electric Lyme, the coming of electricity to an English seaside town. ISBN 13 978-0-95526750-5. Martin Roundell Greene, Crewkerne, Somerset, UK. pp182.

Hansard. 2004. Market Towns Initiative, Question by Andrew George, MP, to Alun Michael, MP, Minister of State. United Kingdom Parliament, London. Available : <http://tinyurl.com/7ay7ew5>. Accessed: 09 December 2013.

HLF. 2013. Awards for all England. Big Lottery Fund UK, London. Available at: <http://tinyurl.com/nsj5mz5>. Accessed: 23 December 2013.

Ignatieff, M. 2014. Free polarised politics from its intellectual vacuum. The Financial Times, 09 January 2014. Available : 〈http://tinyurl.com/qxrrda5>. Accessed: 15 January 2014.

James, N. and Waldron, C. 2010. Thinking about Rural Transport: Implications of an International Review of Rural Transport undertaken for the CRC. Sustainable Transport Advice and Research Independent Consultants Ltd., Nottingham, UK. Available at: <http://tinyurl.com/q5gvgca〉. Accessed: 21 December 2013.

JRF. 1995. Evaluating rural housing enablers. ISSN 0958-3084. Joseph Rowntree Foundation, York, UK.

Kersley, A. 2013. Rural Housing Enabler, Theale, Reading, Berkshire, UK. Pers. Com.

LGA. 2012. Rewiring Public Services. Local Government Association, London. Available at: <http://tinyurl.com/pju9y8o>. Accessed: 31 December 2013.

LGA. 2013. LGA response to the Local Government Finance Settlement. Local Government Association, London. Available at: 〈http://tinyurl.com/qyqk7x4 >. Accessed: 31 December 2013.

London Ancestor. 2013. A List of all market Towns in England and Wales, 1722: with the days of the week thereon kept. In: Stow, W., Remarks on London, being an exact survey of the cities of London and Westminster, Borough of Southwark . Available at: <http://tinyurl.com/nszhgjr >. Accessed: 28 November 2013.

Morris, G.R. 2010. People Helping People. An Assessment of the Market Towns Initiative and Related Initiatives, and the Extent to Which They Addressed Rural Poverty. University of Exeter, Devon, UK. Available at <http://hdl.handle.net/10036/3076>. Accessed 05 December 2013.

Moseley, M.A. and Clark M. 1998. An Evaluation of the Impact of Dorset Rural Development Programme, 1994-1998. Countryside \& Community Research Unit, Cheltenham and Gloucester College of Higher Education (now the University of Gloucestershire), Cheltenham, Glos. GL50 4AZ. pp58.

NALC. 2008. A guide to becoming a quality council. National Association of Local Councils, London. pp46.

NALC. 2010. Localism in Practice. National Association of Local Councils, London. pp44.

NALC. 2012. Quality Parishes Scheme. Transitional arrangements while the scheme is being reviewed. National Association of local Councils, London. pp2.

NESTA. 2013. Public Service Transformation Network. Available at: 〈http://tinyurl.com/pm3clkd >. Accessed: 31 December 2013.

NEF. 2005. Clone Town Britain. New Economics Foundation, London. pp40.

New Milton. 2012. The New Milton Regeneration Project : 2006 - 2008. New Milton Town Partnership, Hampshire, UK. Available at: <http://tinyurl.com/ot67q2m>. Accessed: 10 January 2014.

Nichols, C. 2005. Beacon Towns: The Story Continues. The Countryside Agency, Cheltenham, Gloucestershire, UK. pp176.

Nichols, C. 2005a. Gateway Stations: A Partnership Story - Final Report on the two-year Pilot Programme. The Commission for Rural Communities, Cheltenham. Gloucestershire. pp52.

Northants ACRE. 2013. Rural Transport. Northamptonshire ACRE, Northampton, Northamptonshire, UK. Available at: <http://tinyurl.com/npkhsr8>. Accessed: 21 December 2013.

Odgers, W.B. 1899. Local Government. Macmillan \& Co., London (reproduced by BiblioBazaar, P.O. Box 21206, Charleston, USA). 
Powe, N., Hart, T., and Shaw, T. 2007. Market Towns, Roles, Challenges and Prospects. Routledge, London.

P. 2011. Neighbourhood Planning. Planning Portal, Department for Communities and Local Government, London. Available at: 〈http://tinyurl.com/dynmmnp〉. Accessed: 22 December 2013.

RDC. 1993. The Rural Housing Problem. Rural Development Commission, Salisbury, Wiltshire, UK. pp7.

RERC. 2005. Defra Classification of Local Authority Districts and Unitary Authorities in England. A Technical Guide. Rural Evidence Research Centre, Birkbeck College, University of London. Available at: <http://tinyurl.com/pdbkgal>. Accessed: 04 December 2013.

Scottish Government. 2009. Review of Rural Housing Enablers, Part 6.” The Scottish Government, Edinburgh, Scotland, UK. Available at: <http://tinyurl.com/o3ztco6>. Accessed: 22 December 2013.

Shapps, G. 2012. Portas Pilots Prospectus: an invitation to become a Town Team. Department for Communities and Local Government, London. ISBN: 978-1-4098-3338-3. Available at: 〈http://tinyurl.com/qbv592w>. Accessed: 31 December 2013.

Stevens, A. 2006. The Politico's Guide to Local Government ( $2^{\text {nd }}$ Ed.). Politico's Publishing, Methuen Ltd., London.

Shepherd, J. 2009. A Typology of the Smaller Rural Towns of England. Research Note, Rural Evidence Research Centre, Birkbeck College, University of London. Available at: <http://tinyurl.com/njdqura > Accessed: 15 December 2013.

Shepherd, J. 2013. Map of England's Towns, Rural Evidence Research Centre, Birkbeck College, London.

SRYP. 2013. Moped Loan Scheme. Somerset Rural Youth Project, Bridgwater, Somerset, UK. Available at: <http://tinyurl.com/3hdr9rh). Accessed: 22 December 2013.

Towns Alive. 2013. Towns Alive National Awards 2013. Towns Alive (Action for Market Towns), Bury St. Edmunds, Suffolk, UK. Available at: <http://tinyurl.com/o7bqms6> Accessed 07 March 2014.

Trussell Trust. 2013. Restoring Dignity and Reviving Hope. The Trussell Trust, Salisbury, Wiltshire, UK. Available at: < http://tinyurl.com/3so4alh> Accessed 04 December 2013.

UK Parliament. 2013. Housing. Rural Communities, Environment, Food and Rural Affairs Committee, Parliamentary Business Publications and Records, UK Parliament, London. Available at: <http://tinyurl.com/pgqxwvz>. Accessed: 22 December 2013.

WDDC. 2012. Affordable Housing Scheme - Buckland Newton. West Dorset District Council, Dorchester, Dorset, UK. Available at: <http://tinyurl.com/oplktk9 >. Accessed: 11 January 2014.

Wikipedia. 2013. List of towns in England. Available at: <http://tinyurl.com/gldoo> Accessed: 28 November 2013.

Wintour, P. 2013. Danny Alexander aims to save billions by cutting duplication in public services. Chief secretary to the Treasury plans to scale up successful pilot schemes, which are on course to save $£ 800$ million over five years. The Guardian. 21 March 2013. Available at: <http://tinyurl.com/qfgbwa6>. Accessed: 31 December 2013.

Woods, M. 2005. Rural Geography. London: Sage Publications Ltd.. 